International Research Journal of Management, IT \& Social Sciences
Available online at https://sloap.org/journals/index.php/irjmis/
Vol. 6 No. 6, November 2019, pages: 135 145
ISSN: 2395-7492
https://doi.org/10.21744/irjmis.v6n6.780

\title{
Success Implementation of Online Technology Information System on Market Cooperative Kumbasari Denpasar
}

\begin{abstract}
CrossMark
Putu Yadnya ${ }^{a}$

Herkulanus Bambang Suprasto b

Anak Agung Ngurah Bagus Dwirandra ${ }^{c}$

I Gusti Ngurah Agung Suaryana ${ }^{d}$

Article history:

Received: 09 July 2019

Accepted: 30 September 2019

Published: 29 October 2019

Abstract

The research was intended at identifying the contribution of system quality influences toward use and user satisfaction. The primary data in the current was obtained directly from the questionnaire. The method used to obtain data was non-participant observation using a questionnaire. The list of structured questions asked to field officers and back-officers and unit managers in the market cooperative Kumbasari Denpasar. It was conducted in all market cooperative service units of Kumbasari Denpasar. There were 14 units located in traditional markets in Denpasar, Gianyar, and Badung. The study result showed system quality influences towards use of online-based cooperative information system. It was due to the system users believe the reliability of the system used in performing daily tasks. The running system was able to answer the needs of users of online-based cooperative information system. The system quality influences user satisfaction towards online cooperative information system. The reliability of the information system was built also influences the level of user satisfaction system. It was due to the most user of information system believe and feel the system can facilitate their work. Therefore, they can easily do relying their work on existing information systems.
\end{abstract}

2395-7492@ Copyright 2019. The Author. This is an open-access article under the CC BY-SA license (https://creativecommons.org/licenses/by-sa/4.0/) All rights reserved.

\section{Author correspondence:}

Putu Yadnya,

Accounting Magister Study Program, Faculty of Economics and Business, Udayana university, Denpasar

Email address: yads_putu@yahoo.co.id

\footnotetext{
${ }^{a}$ Udayana University, Denpasar, Indonesia

${ }^{\mathrm{b}}$ Udayana University, Denpasar, Indonesia

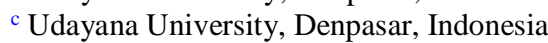

${ }^{\mathrm{d}}$ Udayana University, Denpasar, Indonesia
} 


\section{Introduction}

The business agency on cooperative is one of the profit-oriented business entities for welfare. All members and society are generally stated in the objectives of cooperatives according to the Cooperative Law No. 25/1992. The effort to realize these objectives, cooperatives are required to be able to compete in the arena industrial supply by optimizing cooperative management performance. Market cooperative Kumbasari Denpasar is a savings and loan cooperative. The running business in the financial sector by providing financial services to traders in Kumbasari and Badung markets as well as in other traditional markets. Since, its establishment in 1981 to present, it has had 14 supporting units located in 14 traditional markets in the cities of Denpasar, Badung, and Gianyar. These auxiliary units provide financial services to members in their respective regions. It is under the coordination of its central unit located in Kumbasari market. All strategic policies are determined by the management in the Central Unit. An auxiliary unit is led by a unit manager who is responsible for all activities and services in their respective units, ranging from service issues to members, human resource issues as well as daily reporting and monthly reports. Members of market cooperative Kumbasari up to 2018 have reached more than 13.000 spread across 14 areas of Denpasar, Badung, and Gianyar. Most of the members are traders in traditional markets in 14 regions.

Since 2002, market cooperative Kumbasari Denpasar in running its business began implementing information technology (IT) based savings and loan applications. The savings and loan application still stood alone. It was only used to manage data independently in each central unit and its supporting units. All financial services, for example, savings, loans, and term deposits are served with the help of the savings and loan application. The application of savings and loan application makes market cooperative Kumbasari have implemented IT in its business. Many similar businesses still do not implement IT. It has brought about a very fundamental change in the service and reporting system, as well as making market cooperative Kumbasari that pioneered the use of IT-based systems. In fact, the application system applied has been able to support the entire performance of cooperative Kumbasari to present. The period 2002 to 2018, there have been renewal application systems have been implemented. The aim is to increase service capacity through the addition of application features (Udayana, 2017; Xavier, 2015).

User satisfaction makes the cooperative able to face competitive competition. The management demands to always provide the best information and services. It always tries to be more than its competitors, therefore, the company needs the right system to support operations in its business. Errors in the system selection will have adverse consequences for the company both financially and non-financially. Financial loss can be in the form of a decrease in revenue obtained by the company. Non-financial losses can be in the form of customer complaints and even loss of customers. Normasari (2013), stated service quality directly influences user satisfaction.

In the first quarter of 2019, market cooperative management of Kumbasari wishes to upgrade again the cooperative application system that was applied. It has given an increasing number of cooperative members. The wider service was provided to cooperative members and customers. The application has applied the development of the previous application. The new application is more emphasis on service flexibility through online services for field collectors. Implementing a new application system, it is hoped it will further optimize the performance of field workers in conducting data collection and providing efficient services to customers. There are two research questions discussed in the present study. What is the system quality influences the use and user satisfaction?

\section{Literature Review}

Romney \& Steinbart (2014), defined an accounting information system (AIS) is a system that collects, records, stores, and processes data to produce information for decision-makers. This system includes people, procedures and instructions, data, software, information technology infrastructure, as well as internal control, and security measures. An accounting information system can also be defined as a group of structures within an entity that manages other resources to convert economic data into accounting information. In order to meet the information needs of various parties (Mahatmyo, 2014).

A cooperative information system is applied in cooperative market Kumbasari Denpasar actually one type of information system for managing primary data into secondary data and financial reports. Primary data in question are data obtained from the field officers on transactions that occurred. Starting from savings deposit and deposit transactions, loan realization, installment transactions, cashier transactions, and bank transfers.

The cooperative system was built in two platforms, namely desktop and web-base. The two platforms are respectively to adjust the media used. Desktop applications are used to record transactions in local area network (LAN), namely, on a local network with one server with several workstations. Desktop applications are built as back-office 
applications. Conversely, to obtain the influences of the input process, a system with a web-base is built. Therefore, the field officer can enter data through online media (web-base), namely Android peripherals or smartphones.

A good model is a complete but simple model. DeLone \& McLean (1992), put forward the information system success model known as the D\&M IS Success Model, as follows.

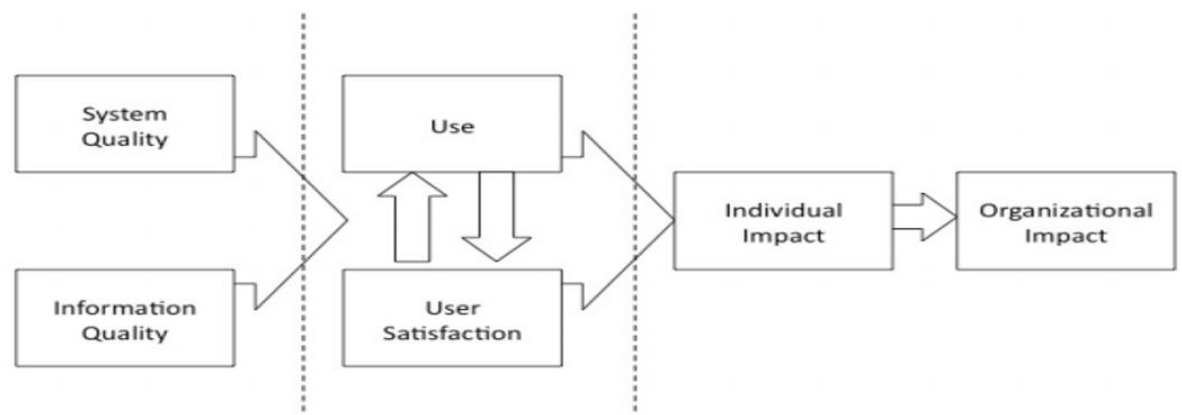

Figure 1. DeLone \& McLean (1992) information systems success model

The basic concept of DMSM (DeLone \& McLean Information System Success Model) has six measurements of information system success, namely system quality, information quality, use, user satisfaction, and individual impact and organizational impact. DeLone \& McLean (2003), proposed an updated model is shown in the following Figure 2.

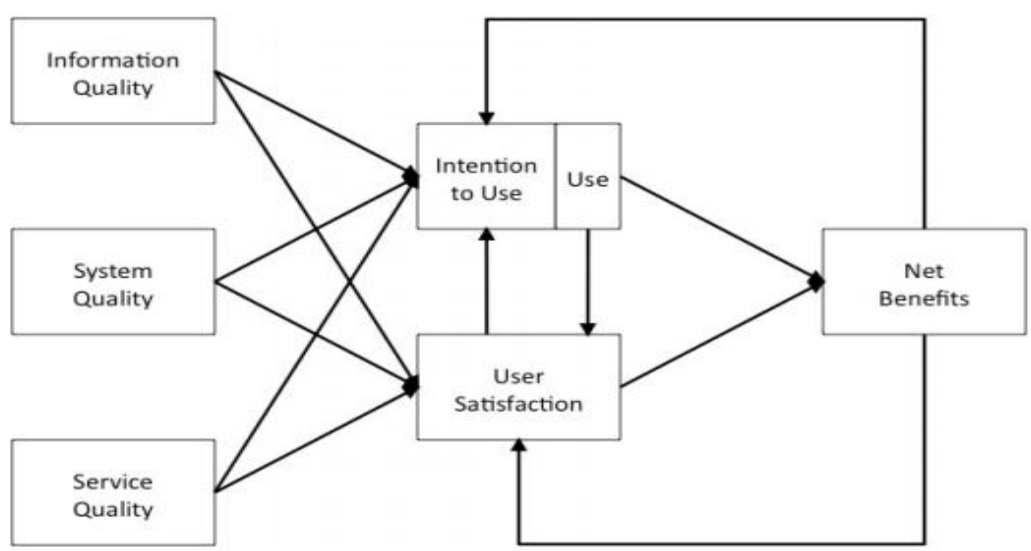

Figure 2. Updated D\&M IS Success Model (DeLone \& McLean, 2003)

Kim (1988), stated the competition between HAIS task predictive capability and coordination mode is significantly related to performance as measured by information user satisfaction. Data collection methods used in quantitative research questionnaires, with HAIS field surveys including observation and group development. The finding showed the comparison between HAIS task predictability abilities and coordination modes is significantly related to good performance as measured by user information satisfaction. The use of user information satisfaction (UIS) as a substitute for measures for MAS performance results in better performance.

Hudin \& Riana (2016), resulted regarding nine hypotheses, six is significant information quality has a significant influences on user satisfaction, system quality has a significant influences on usage, system quality has a significant influences on satisfaction, service quality has a significant influences on user satisfaction, use has a significant influences on user satisfaction, use has a significant influences on net benefits, user satisfaction has a significant influences on net benefits. Two other hypotheses are not proven, namely information quality has a significant influence on use and service quality has a significant influence on use.

Jumardi et al., (2015), the result showed user satisfaction on the thesis information system is influenced by information quality and system quality. The net benefit is influenced by user satisfaction. Service quality has no

Yadnya, P., Suprasto, H. B., Dwirandra, A. A. N. B., \& Suaryana, I. G. N. A. (2019). Success implementation of online technology information system on market cooperative kumbasari denpasar. International Research Journal of Management, IT and Social Sciences, 6(6), 135-145. https://doi.org/10.21744/irjmis.v6n6.780 
influence on user satisfaction. The thesis information system has provided benefits to the user, but in implementing the thesis information system students as users feel the need to improve the quality of the service.

\section{Materials and Methods}

\section{Research Hypothesis}

Influences of system quality on use. Information system quality usually focuses on the characteristics of system performance. If the user information system believes the quality of the information system used is good, then the user of the accounting information system will increase. The higher the system quality, the more use of accounting information systems. The system is confirmed to be successful if the system quality produced can provide useful information and can increase the use of information systems. Hudin \& Riana (2016), stated that system quality has a significant influence on use. The following hypothesis is:

\section{H1: System quality influences on the use}

Influences of system quality on user satisfaction. If the user information system believes used is good. The user will feel satisfied. The higher system quality, the higher the user satisfaction of the information system. The system is stated to be successful if system quality produced by the system can provide comfort that will increase satisfaction for the user information system. Jumardi et al., (2015), stated system quality significantly influences user satisfaction. The following hypothesis is:

H2: System quality influences user satisfaction.

The research design is a comprehensive study plan covers all the things. It will be conducted on researchers ranged from formulating hypotheses and their operational implications to the final analysis. Data is then concluded and given advice (Giri, 2014). The research design is a framework shows the variables studied and describes the steps for each research activity (Jogiyanto, 2007). Designing research defines determining each research type, determining data to be used and designing empirical models to test hypotheses that are formulated.

This study based on the research phenomenon. The research phenomenon is a thing or symptom that arise of interest to researchers to conduct research. Based on theoretical and empirical studies, several variables are used in the designed study. The first endogenous variable is the net benefits. The two exogenous variables are information quality, system quality, service quality, user, and user satisfaction. Then the research problem is formulated and the research hypothesis is made.

The primary data is obtained directly from the questionnaire. The method used to obtain data is non-participant observation and using a questionnaire list of structured questions asked to field officers and back-office and unit managers in market cooperative Kumbasari Denpasar. This research was conducted in all market cooperative service units of Kumbasari Denpasar. There were 14 units located in traditional markets in Denpasar, Gianyar, and Badung.

The population is a generalization area consisting of objects or subjects that have certain qualities and characteristics determined by researchers to be studied and then drawn conclusions (Sugiyono, 2014). The population in this study were all field officers and back-office and unit managers in cooperative market Kumbasari Denpasar. The sample is part of the number of characteristics possessed by the population. A sample is a number of members drawn. Sampling was carried out using the nonprobability sampling method with a saturated sample technique. The sample is the same as the study population. It is all the entire field staff and back-office and unit managers.

\section{Results and Discussions}

\subsection{Data Analysis}

Questionnaire data was filled in by 87 respondents from users of the online cooperative information system was processed using SmartPLS version 3.0. PLS can simultaneously conduct measurement model testing as well as structural model testing.

a) Evaluation of the outer model

The evaluation of structural models is to measure the correlation between indicators and constructs/latent variables. 
Knowing the correlation will be known as the validity and reliability of a model. In order to measure the construct validity and reliability, it is conducted looking at convergent validity, discriminant validity, and construct reliability (Ghozali 2008).

b) Convergent validity

The convergent variable aims to determine the validity of each correlation between the indicator and its latent variable. The validity test was calculated using Smart PLS. The test is based on the outer loading value of the indicator and will be considered valid if it has an outer loading value greater than 0.70 (Ghozali 2008). The following are the results of outer loading for each of the indicators of data processing using Smart PLS.

Table 1

The outer loading of each indicator

\begin{tabular}{llll}
\hline Variable & Code & Test results & Information \\
\hline System Quality & KS.01 & 0.883 & Valid \\
& KS.02 & 0.836 & Valid \\
KS.03 & 0.831 & Valid \\
KS.04 & 0.831 & Valid \\
KS.05 & 0.671 & Invalid \\
Information Quality & KS.06 & 0.911 & Valid \\
& KI.01 & 0.896 & Valid \\
& KI.02 & 0.764 & Valid \\
Service Quality & KI.03 & 0.797 & Valid \\
& KI.04 & 0.692 & Invalid \\
Use & KI.05 & 0.838 & Valid \\
& KC.01 & 0.931 & Valid \\
User Satisfication & KC.02 & 0.956 & Valid \\
& KC.03 & 0.895 & Valid \\
Net Benefit & U.01 & 0.959 & Valid \\
& U.02 & 0.949 & Valid \\
& US.01 & 0.961 & Valid \\
& US.02 & 0.967 & Valid \\
& BF.01 & 0.917 & Valid \\
& BF.02 & 0.896 & Valid \\
& BF.03 & 0.944 & Valid
\end{tabular}

Source: Data processed (2019)

All indicators have loaded is greater than 0.70 but there are two indicators namely KS.05 and KI.04 have values below 0.70 namely 0.671 and 0.692 . The values indicate the item has low validity due to it is not in accordance with the requirements namely above 0.70 . Items less than 0.70 consisting of KS. 05 for the construct of the system quality and indicator KI.04 for the construct of information quality, must be removed/done dropping from the model before the next stage of testing is carried out.

Dropping on items has a value below standard, then does a re-estimation to provide confidence to all items that have a value of more than 0.70 . The results of the re-estimation can be seen in the following Table 2:

Table 2

Outer loading values after re-estimation

\begin{tabular}{llll}
\hline Variable & Code & Test results & Information \\
\hline System Quality & KS.01 & 0.883 & Valid \\
& KS.02 & 0.836 & Valid \\
& KS.03 & 0.831 & Valid \\
& KS.04 & 0.831 & Valid \\
Information Quality & KS.06 & 0.911 & Valid \\
\hline
\end{tabular}

Yadnya, P., Suprasto, H. B., Dwirandra, A. A. N. B., \& Suaryana, I. G. N. A. (2019). Success implementation of online technology information system on market cooperative kumbasari denpasar. International Research Journal of Management, IT and Social Sciences, 6(6), 135-145. https://doi.org/10.21744/irjmis.v6n6.780 


\begin{tabular}{llll}
\hline & KI.02 & 0.764 & Valid \\
& KI.03 & 0.797 & Valid \\
Service Quality & KI.05 & 0.838 & Valid \\
& KC.01 & 0.931 & Valid \\
Use & KC.02 & 0.956 & Valid \\
\multirow{2}{*}{ User Satisfication } & KC.03 & 0.895 & Valid \\
\multirow{3}{*}{ Net Benefit } & U.01 & 0.959 & Valid \\
& U.02 & 0.949 & Valid \\
& US.01 & 0.961 & Valid \\
& US.02 & 0.967 & Valid \\
& BF.01 & 0.917 & Valid \\
& BF.02 & 0.896 & Valid \\
\hline
\end{tabular}

Source: Data processed (2019)

The re-estimation results above show that all indicator loads are greater than 0.70 , indicating all indicators have met the convergent validity requirements.

c) Discriminant validity

Ghozali (2008), argued discriminant validity of the outer model with reflexive indicators is assessed based on crossloading measurements with constructs. The value is a cross-loading factor value which is useful to know whether the construct has adequate discriminant comparing the loading value of the intended construct must be greater than the other construction loading values. The results of discriminant validity in the cross-loading value Table 3 :

Table 3

Cross Loading Value

\begin{tabular}{lllllll}
\hline Indicator & $\begin{array}{l}\text { Information } \\
\text { Quality } \\
(\mathrm{KI})\end{array}$ & $\begin{array}{l}\text { System } \\
\text { Quality } \\
(\mathrm{KS})\end{array}$ & $\begin{array}{l}\text { Service } \\
\text { Quality } \\
(\mathrm{KC})\end{array}$ & $\begin{array}{l}\text { Use } \\
(\mathrm{U})\end{array}$ & $\begin{array}{l}\text { User } \\
\text { Satisfication } \\
(\mathrm{US})\end{array}$ & $\begin{array}{l}\text { Benefit } \\
(\mathrm{BF})\end{array}$ \\
\hline KS.01 & 0.604 & 0.883 & 0.536 & 0.579 & 0.550 & 0.600 \\
KS.02 & 0.585 & 0.836 & 0.480 & 0.591 & 0.476 & 0.454 \\
KS.03 & 0.436 & 0.831 & 0.391 & 0.544 & 0.411 & 0.310 \\
KS.04 & 0.525 & 0.831 & 0.406 & 0.517 & 0.501 & 0.424 \\
KS.05 & 0.362 & 0.671 & 0.398 & 0.439 & 0.187 & 0.276 \\
KS.06 & 0.624 & 0.911 & 0.675 & 0.734 & 0.594 & 0.546 \\
KI.01 & 0.896 & 0.579 & 0.645 & 0.722 & 0.649 & 0.465 \\
KI.02 & 0.764 & 0.436 & 0.613 & 0.537 & 0.433 & 0.266 \\
KI.03 & 0.797 & 0.502 & 0.538 & 0.628 & 0.464 & 0.236 \\
KI.04 & 0.692 & 0.393 & 0.458 & 0.456 & 0.280 & 0.177 \\
KI.05 & 0.838 & 0.614 & 0.497 & 0.725 & 0.514 & 0.296 \\
KC.01 & 0.652 & 0.569 & 0.931 & 0.648 & 0.519 & 0.409 \\
KC.02 & 0.658 & 0.597 & 0.956 & 0.682 & 0.587 & 0.489 \\
KC.03 & 0.602 & 0.471 & 0.895 & 0.587 & 0.484 & 0.444 \\
U.01 & 0.765 & 0.704 & 0.686 & 0.959 & 0.587 & 0.361 \\
U.02 & 0.724 & 0.615 & 0.630 & 0.949 & 0.540 & 0.275 \\
US.01 & 0.566 & 0.512 & 0.569 & 0.547 & 0.961 & 0.546 \\
US.02 & 0.600 & 0.581 & 0.539 & 0.592 & 0.967 & 0.608 \\
BF.01 & 0.246 & 0.429 & 0.419 & 0.204 & 0.488 & 0.917 \\
BF.02 & 0.292 & 0.403 & 0.371 & 0.164 & 0.425 & 0.896 \\
BF.03 & 0.453 & 0.608 & 0.513 & 0.479 & 0.682 & 0.944 \\
\hline
\end{tabular}

Source: Data processed (2019)

Table 3 is the result of cross-loading estimation shows the construct correlation value with the indicator is greater 
than the other values. It shows the difference in value or loading of each indicator with their respective latent variables and other latent variables. It can be concluded that all latent variables can be confirmed to be valid and can be used with loading values greater than 0.70 and have met the discriminant validity.

d) The average variance extracted (AVE)

The method to assess discriminant validity on looking at the cross-loading value is to look at the square-based AVE for each construct whether it is greater than the correlation between constructs and other constructs.

Table 4

Average Variance Extracted (AVE)

\begin{tabular}{llll}
\hline Indicator & Value AVE & Base AVE & Info. \\
\hline Information Qulity & 0.641 & 0.801 & Valid \\
System Quality & 0.690 & 0.831 & Valid \\
Service Quality & 0.860 & 0.927 & Valid \\
Use & 0.910 & 0.954 & Valid \\
User Satisfication & 0.929 & 0.964 & Valid \\
Net Benefit & 0.844 & 0.919 & Valid \\
\hline
\end{tabular}

Source: Data processed (2019)

Having seen Table 4 above is AVE value. It is a value indicates each latent variable with the indicator has an appropriate correlation and is greater than 0.50. AVE square-based value for each correlation is greater than the correlation between constructs in the model. It has good discriminant validity. It indicates the indicators used have met the convergent validity and can be used for further analysis.

e) Reliability test/composite reliability

The reliability test is looking at composite reliability. Composite reliability tests the reliability value of indicators in a construct. The reliability test in this study aims to assess the extent to which the measuring instruments used reliable or trustworthy. Discriminant validity can also be seen from the Cronbach Alpha value. The construct is declared reliable if the composite reliability and Cronbach alpha values are above 0.70 . The results can be seen in the following Table 5:

Table 5

Composite reliability and Cronbach alpha

\begin{tabular}{lll}
\hline Indicator & Composite Reliability & Cronbach's Alpha \\
\hline Information Qulity & 0.899 & 0.860 \\
System Quality & 0.930 & 0.909 \\
Service Quality & 0.949 & 0.918 \\
Use & 0.953 & 0.902 \\
User Satisfication & 0.963 & 0.924 \\
Net Benefit & 0.942 & 0.910 \\
\hline
\end{tabular}

Source: Data processed (2019)

Table 5 above shows the value of the composite reliability and Cronbach alpha is greater than 0.70 . Thus, it can be concluded the questionnaire used is consistent and has good reliability.

f) Inner model

The inner model describes the correlation between latent variables in the model. Assessing inner models can be conducted looking at structural models that consist of a hypothesized correlation between latent constructs in the research model. There are two variables, namely the independent variable does not have the value $R^{2}$. Due to the variable is not influenced by other variables in the model. It can be seen $\mathrm{R}$-square value from endogenous constructs or the dependent variable namely user satisfaction variables, use variables, net benefit variables. The R-square test results can be seen in Table 6 for the dependent variables.

Yadnya, P., Suprasto, H. B., Dwirandra, A. A. N. B., \& Suaryana, I. G. N. A. (2019). Success implementation of online technology information system on market cooperative kumbasari denpasar. International Research Journal of Management, IT and Social Sciences, 6(6), 135-145. https://doi.org/10.21744/irjmis.v6n6.780 
Table 6

R-square

\begin{tabular}{ll}
\hline Indicator & R Square \\
\hline Use & 0.696 \\
User Satisfaction & 0.447 \\
Benefit & 0.360 \\
\hline \multicolumn{2}{c}{ Source: Data processed (2019) }
\end{tabular}

$\mathrm{R}$-square value for use is 0.696 defines the presentation of the influence of system quality, information quality, and service quality is $69.6 \%$ while the remaining $30.4 \%$ is influenced by other parties. R-square value for user satisfaction is 0.451 means the percentage of influence on the system quality, information quality, and service quality is $45.1 \%$ while the remaining $54.9 \%$ is influenced by other factors. R-square value for net benefits is 0.360 means the percentage of influence on use and user satisfaction is $36.0 \%$ while the remaining $64.0 \%$ is influenced by other factors.

Testing R-square value can also be carried out testing stages with the goodness of fit. It can be known through the value $\left(Q^{2}\right) . Q^{2}$ value has the same meaning as the determination coefficient (R-Square) in the regression analysis. Wherein the higher R-square, the model can be stated to be more fit with the data. Table 6 can be calculated as the $\mathrm{Q}^{2}$ value as follows:

$$
\begin{aligned}
\text { Value } Q^{2} & =1-(1-0,696) \times(1-0,451) \times(1-0,360) \\
& =1-(0,304 \times 0,549 \times 0,640) \\
& =0,893
\end{aligned}
$$

The calculation result shows $\mathrm{Q}^{2}$ value of 0.893 means the diversity magnitude of the research data can be explained the structural model developed in this study is $89.3 \%$. Based on these results, the inner model already has good goodness of it. They can be seen in the path diagram graph from the results of data processing.

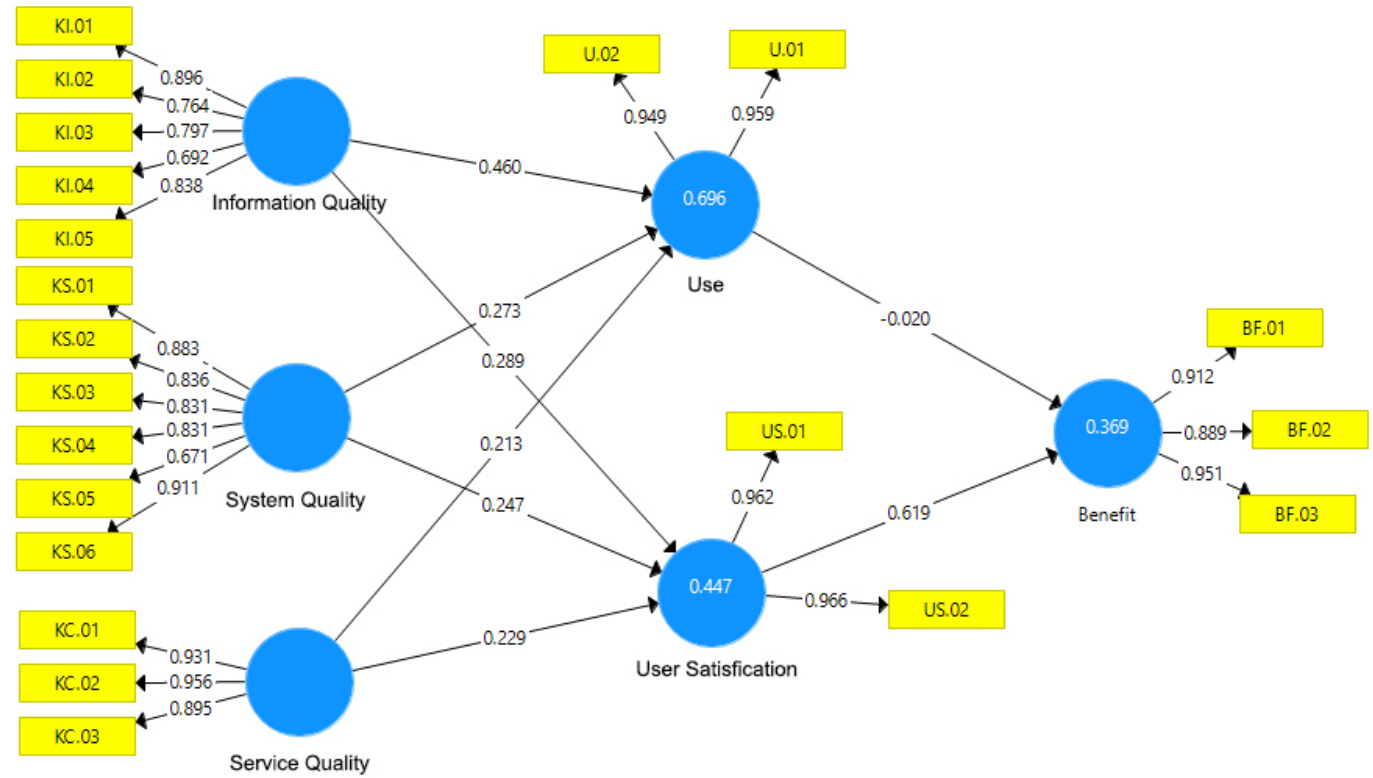

Figure 3. Path diagram

Source: Data processed (2019)

g) Hypothesis test

The researchers used the Bootstrapping method on Smart PLS, standard errors (path errors), path coefficients $(\beta)$, and T-statistics values can be obtained. We can assess the statistical significance of the research model using this technique, on testing hypotheses for each path of correlation. The following Table 7 shows the coefficients for each 
hypothesis path and their T-statistics values.

Table 7

Path coefficient and statistics t-value

\begin{tabular}{llllll}
\hline Correlation & $\begin{array}{l}\text { Original } \\
\text { Sample (O) }\end{array}$ & $\begin{array}{l}\text { Sample } \\
\text { Mean (M) }\end{array}$ & $\begin{array}{l}\text { Standard Deviation } \\
(\mathrm{STDEV})\end{array}$ & $\begin{array}{l}\text { T Statistics } \\
(\mid \mathrm{O} / \mathrm{STDEV})\end{array}$ & $\begin{array}{l}\mathrm{P} \\
\text { Values }\end{array}$ \\
\hline $\begin{array}{l}\text { Information Qulity -> User } \\
\text { Satisfication }\end{array}$ & 0.289 & 0.277 & 0.110 & & \\
$\begin{array}{l}\text { Information Qulity -> Use } \\
\text { System Quality -> User }\end{array}$ & 0.460 & 0.444 & 0.114 & 2.622 & 0.009 \\
$\begin{array}{l}\text { Satisfication } \\
\text { System Quality -> Use }\end{array}$ & 0.248 & 0.244 & 0.112 & & 0.000 \\
Service Quality -> User & 0.273 & 0.275 & 0.112 & 2.206 & 0.028 \\
Satisfication & & & & 2.438 & 0.015 \\
Service Quality -> Use & 0.229 & 0.244 & 0.127 & 1.809 & 0.071 \\
Use -> Benefit & 0.213 & 0.230 & 0.107 & 2.002 & 0.046 \\
User Satisfication -> Benefit & -0.029 & -0.039 & 0.120 & 0.246 & 0.806 \\
\hline
\end{tabular}

Source: Data processed (2019)

Hypothesis test in this hypothesis used a significance level of 5\% and a confidence level of 95\%. Therefore, the tstatistic must be $>1.96$. If the T-statistic is higher than the T-table value, it means the hypothesis is supported or accepted.

Based on data from Table 7 above shows T-statistics greater than 1.96 proves that five hypotheses were accepted. P-value less than 0.5 indicate significantly influences. The following are the results of hypothesis test of each variable.

(1) H1: System quality influences the use of online-based cooperative information system. Table 7 shows system quality of use gives a path coefficient of 0.273 on t-statistic value. 2.484 and has p-value of 0.013 (T-statistics $>$ T-table 1.96). it is to show system quality influences the use of online-based cooperative information system, it can be stated hypothesis 1 is supported. Due to t- value statistic meets the requirements, namely T-statistic > T-table 1.96.

(2) H2: System quality influences on user satisfaction of online cooperative information system. The system quality towards user satisfaction gives a path coefficient of 0.248 and has a p-value of 0.018 and t-statistic value of 2.367 (T-statistics > T table 1.96). it is to show system quality influences user satisfaction using online cooperative A system. Therefore, it can be stated hypothesis 2 is supported. Due to t-statistics value meets the requirements, namely T-statistics > T-table 1.96 .

\subsection{Discussions}

Testing on two hypotheses proposed in this study accepted. This discussion aims to explain theoretically the hypothesis results test and analysis for its influences. This study adopted the theory of information system success by DeLone and McLean was updated in 2003. This study uses several variables, namely system quality, information quality, service quality, use, user satisfaction, and net benefits.

(1) System quality influences the use of an online-based cooperative information system.

$H 1$ acceptance stated the system quality influences the use of an online-based cooperative information system, indicates that a good quality system will increase the intensity of the use. If the system quality is reliable, it will increase the intention to use the online-based cooperative information system.

The system quality has a significant influence on the use of an online-based cooperative information system, supported by field data based on questionnaires that have been filled out by respondents. Based on responses to statements for the system quality construct consisting of six statements representing indicators of access comfort, system flexibility, the realization of user satisfaction, the usefulness of specific functions, system reliability, and response time. Indicators of the usefulness of specific functions, system reliability, and response time are strong predictors of the use of an online-based cooperative information system.

Market cooperative Kumbasari Denpasar needs to maintain and increase the usefulness of the specific functions

Yadnya, P., Suprasto, H. B., Dwirandra, A. A. N. B., \& Suaryana, I. G. N. A. (2019). Success implementation of online technology information system on market cooperative kumbasari denpasar. International Research Journal of Management, IT and Social Sciences, 6(6), 135-145. https://doi.org/10.21744/irjmis.v6n6.780 
of system reliability and response time to the use of online-based cooperative information system. It is based online has specific functions that suit the needs can respond quickly to requests for information needed by users. The indicators have been able to provide answers to the needs of respondents in increasing the use. For indicators of access convenience system flexibility and realization of user, expectations must be maintained in the online-based is currently running. This is consistent with the results of research Hudin \& Riana (2016), which stated that the system quality has a significant influence on use. Thus, the perceived system quality significantly towards the use of online-based cooperative information systems can be confirmed to be successful.

(2) System quality influences on user satisfaction online-based cooperative information system.

$H 2$ acceptance stated system quality has a significant influence on user satisfaction of an online-based cooperative information system. It indicates that a good quality system will influence the level of user satisfaction. If the system quality is reliable, the user will feel comfortable using an online-based cooperative information system. The result will be the user being satisfied with the online-based cooperative information system.

System quality influences user satisfaction. This is supported by field data in filling out questionnaires by respondents. Based on the construct statement of the system quality consisting of six statements, the results obtained are indicators of the use of specific functions, system reliability and response time are strong predictors of the use of an online-based cooperative information system.

The system quality provided online-based cooperative information system has a direct influence on user satisfaction. It is implemented at market cooperative Kumbasari Denpasar has been able to provide satisfaction to the wearer through the use of specific functions, system reliability and response time of the information system. This is in accordance with the results Jumardi et al., (2015), stated system quality significantly influences user satisfaction. Thus, the perceived system quality significantly to the satisfaction of user of online-based cooperative information system can be confirmed to be successful.

\section{Conclusion}

Based on the results of statistical data analysis and discussion on the research on the influence of system quality, using the DeLone \& McLean Update Models, it can be concluded. (1) System quality influences on the use of an onlinebased cooperative information system. It is due to the system users believe the reliability of the system used in performing daily tasks. The system is able to answer the user's need for an online-based cooperative information system. (2) System quality influences on user satisfaction of online-based cooperative information system. The reliability of the information system is built also influences the level of user satisfaction system. This is due to the most users of information systems believe and feel the system can facilitate their work. Therefore, they can easily do their work relying on the existing information system.

\section{Conflict of interest statement}

The authors declared that they have no competing interests.

\section{Statement of authorship}

The authors have a responsibility for the conception and design of the study. The authors have approved the final article.

\section{Acknowledgments}

The authors would like to thank the reviewer for their consideration the further process of the present paper. Thanks to the editor of IRJMIS for the valuable support, time as well as advice. 


\section{References}

DeLone, W. H., \& McLean, E. R. (1992). Information systems success: The quest for the dependent variable. Information systems research, 3(1), 60-95. https://doi.org/10.1287/isre.3.1.60

Delone, W. H., \& McLean, E. R. (2003). The DeLone and McLean model of information systems success: a ten-year update. Journal of management information systems, $19(4), \quad 9-30$. https://doi.org/10.1080/07421222.2003.11045748

Ghozali, I. (2008). Structural equation modeling: Metode alternatif dengan partial least square (pls). Badan Penerbit Universitas Diponegoro.

Giri, N. C. (2014). Multivariate statistical inference. Academic Press.

Hudin, J. M., \& Riana, D. (2016). Kajian Keberhasilan Penggunaan Sistem Informasi Accurate Dengan Menggunakan Model Kesuksesan Sistem Informasi Delon Dan Mclean. Jurnal Sistem Informasi, 12(1), 1-8. https://doi.org/10.21609/jsi.v12i1.444

Jogiyanto, H. M. (2007). Model kesuksesan sistem teknologi informasi. Yogyakarta: Penerbit Andi.

Jumardi, R., Nugroho, E., \& Hidayah, I. (2015). Analisis Kesuksesan Implementasi Sistem Informasi Skripsi pada Program Studi Teknik Informatika Universitas Pembangunan Nasional "Veteran" Yogyakarta. Jurnal Inovasi dan Kewirausahaan.

Kim, K. K. (1988). Organizational coordination and performance in hospital accounting information systems: An empirical investigation. Accounting Review, 472-489.

Mahatmyo, A. (2014). Sistem Informasi Akuntansi Suatu Pengantar. Deepublish.

Normasari, S. (2013). Pengaruh Kualitas Pelayanan Terhadap Kepuasan Pelanggan, Citra Perusahaan Dan Loyalitas Pelanggan Survei Padatamu Pelanggan Yang Menginap Di Hotel Pelangi Malang. Jurnal Administrasi Bisnis, 6(2).

Romney, M. B., \& Steinbart, P. J. (2014). Accounting Informasi System. Jakarta: Salemba empat.

Sugiyono. (2014). Metode Penelitian Kuantitatif, Kualitatif \& RD. Bandung: Alfabeta.

Udayana, I. G. B. (2017). Marketing strategies arabica coffee with information technology in Kintamani District Bangli. International Research Journal of Engineering, IT \& Scientific Research, 3(3), 93-102.

Xavier, I. M. D. D. G. (2015). Email issue for working at information technology field. International Research Journal of Management, IT and Social Sciences, 2(5), 1-5.

Yadnya, P., Suprasto, H. B., Dwirandra, A. A. N. B., \& Suaryana, I. G. N. A. (2019). Success implementation of online technology information system on market cooperative kumbasari denpasar. International Research Journal of Management, IT and Social Sciences, 6(6), 135-145. https://doi.org/10.21744/irjmis.v6n6.780 